Monuments \& Memory 


\title{
Architectural Crossroads
}

Studies in the History of Architecture

\author{
Vol. 3
}

\author{
Series Editor \\ Lex Bosman, Universiteit van Amsterdam
}

\begin{abstract}
Editorial Board
Dale Kinney, Bryn Mawr College

Wolfgang Schenkluhn, Martin-Luther-Universität Halle Christof Thoenes, Bibliotheca Hertziana, Rome Marvin Trachtenberg, New York University
\end{abstract}

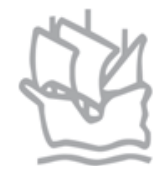


Monuments \& Memory

Christian Cult Buildings and Constructions of the Past

Essays in honour of Sible de BlaAuw

EDITED BY

Mariëtte Verhoeven, Lex Bosman, and

Hanneke van Asperen

酸

BREPOLS 
Cover photo: Nine Miedema, S. Prassede in Rome.

Image editing: Centre for Art Historical Documentation (CKD), Radboud University Nijmegen.

(C) 2016, Brepols Publishers n.v., Turnhout, Belgium.

All rights reserved. No part of this book may be reproduced, stored in a retrieval system, or transmitted, in any form or by any means, electronic, mechanical, photocopying, recording, or otherwise, without the prior permission of the publisher.

$\mathrm{D} / 2016 / 0095 / 215$

ISBN 978-2-503-56973-4

Printed in the EU on acid-free paper 


\section{Contents}

Introduction: Cherished Memories

\section{Monuments}

'In Hoc Signo Vinces':

The Various Victories Commemorated Through the Labarum

Nathalie DE HAAN \& Olivier HEKSTER

Eine vergessene Erinnerung an das byzantinische Rom:

Neudeutung und Rezeptionsgeschichte einer Grabinschrift aus dem 7. Jahrhundert in der S. Cecilia in Trastevere

Raphael G. R. HunSUCKER \& Evelien J. J. ROELS

S. Giovanni in Laterano and Medieval Architecture:

The Significance of Architectural Quotations

Lex BOSMAN

Nikolaus IV. als Erneuerer von S. Giovanni in Laterano und

S. Maria Maggiore in Rom

Peter Cornelius CLAUSSEN

Visiting a 'Home of the Saints':

S. Prassede in Rome

Nine Miedema \& Daniëlle Slootjes

And They Were Always in the Temple:

The Pilgrims' Experience at S. Maria Rotonda

Hanneke VAN ASPEREN

Jerusalem in Aachen

Bianca KÜHNEL

Appropriation and Architecture:

Mary Magdalene in Vézelay

Mariëtte VERHOEVEN

Remembering the Lost Palace:

Explaining and Engaging with the Absence of Constantinople's Great Palace Isabel KIMMELFIELD

The Mausoleum of Helena and the Adjoining Basilica Ad Duas Lauros:

Construction, Evolution and Reception

Dafne Oosten 


\section{Contents}

\section{Places}

Helena Augusta and the City of Rome

Jan Willem DRIJVERS

Epic Architecture:

Architectural Terminology and the Cities of Bethlehem and Jerusalem in the Epics of Juvencus and Proba

Roald DIJKSTRA

Senatoren als Stifter der Kirche im spätantiken Rom

Ralf BEHRWALD

Martyrien und Reliquien, intra' and ,extra muros ${ }^{6}$

im 4. und 5. Jahrhundert

Beat BRENK

The Memory of the Bishop in the Early Christian Basilica

Paolo LIVERANI

,Drehmomente':

Orientierungswechsel christlicher Kultbauten im mittelalterlichen Rom

Daniela MONDINI

199

Sacralizing the Palace, Sacralizing the King:

Sanctuaries and/in Royal Residences in Medieval Europe

Peter RIETBERGEN

209

Fragen an Rom aus dem Umfeld der Bayrischen Jesuiten:

Jakob Rabus' Bedenckhspuncte von 1575

Ingo HERKLOTZ

\section{Decoration and Liturgical Furnishing}

The Twelfth-Century Frescoes 'Iuxta Scala Que Ascendit in Patriarchio'

Herbert L. KESSLER

Clergy and Laity Viewing Both Sides of Painted Altarpieces in Rome, Siena, San Sepolcro and Perugia

Bram KEMPERS

St Jerome and a Church Model:

The Altarpiece of the Brotherhood of the Immadulate Conception in Bergamo

Bram DE KLERCK

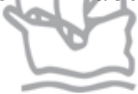

Jerusalem and Other Holy Places As Represented by Jheronimus Bosch

Jos KOLDEWEIJ 
The Choir Stalls of St Martin in Emmerich:

History of a Battered Ensemble

Willy PIRON

The Tree of Charlemagne?

Ecclesiastical and Secular Rulers on Late Medieval Choir Stalls

Christel THeunissen

Persisting Patterns:

Aspects of Continuity in Dutch Church Interiors through the Calvinist Reformation

Justin E. A. KROESEN

Liturgical Revolution at the

Basilica of S. Paolo Fuori le Mura (1560-1610)

Nicola CAMERLENGHI

Managed Memory in S. Maria in Trastevere

Dale KINNEY

Lost Frescoes, a Forgotten Saint and a Rediscovered Play:

S. Magno in Cittaducale Arnold WITTE

The Servatius Chalice in St Servatius Church and Its 'Replica':

Comments on the Origins

Jean-Pierre VAN RIJEN

From Ravenna to Enschede:

A Glass Mosaic of 1933

Lieske TIBBE

A Strange Lostness That Is Palpably Present:

On Gerhard Richter's 'Cologne Cathedral Window'

Wouter WEIJERS

Colour Plates 


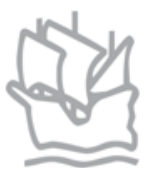

(C) BREPOLS PUBLISHERS

THIS DOCUMENT MAY BE PRINTED FOR PRIVATE USE ONLY. IT MAY NOT BE DISTRIBUTED WITHOUT PERMISSION OF THE PUBLISHER 


\title{
A Strange Lostness That Is Palpably Present: On Gerhard Richter's 'Cologne Cathedral Window'
}

\author{
Wouter WeIJERS
}

When the window that Gerhard Richter had designed for the southern facade of the transept of the Cathedral of Cologne was festively inaugurated with a Holy Mass on 25 August 2007, reactions to his work were, to put it mildly, divided. Opinions also varied among those with administrative, pastoral and cultural duties in the cathedral. Richter had filled the entire neo-Gothic tracery of the 22 metre tall, I $33 \mathrm{~m}^{2}$ window frame with an orderly pattern of II, 263 glass squares in 72 colours, each measuring $9.6 \times 9.6 \mathrm{~cm}$ (Figure I and Colour Plate XIV). The current cathedral's master builder, architect and art historian Barbara Schock-Werner, was filled with admiration:

The vitreous wall of colour with its beguiling light has dispelled all ornament and seems to contain everything that has ever been said about spirituality, light and colour. All thoughts, all images, and all saints are united in his window. ${ }^{\text {I }}$

However, Cardinal Joachim Meisner, Archbishop of Cologne at the time of the window's completion, concluded sorrowfully:

The window does not suit the cathedral. It would be more fitting in a mosque or house of prayer. When we are fortunate enough to get a new window, it should clearly reflect our faith, not just any faith. ${ }^{2}$

Richter himself countered Meisner's criticism by saying that he had not intended to make a Catholic window. ${ }^{3}$ But if a window in that particular place is not a Catholic window, then what is it?

\section{A Short History}

Through the ages, Cologne Cathedral has been a work in progress, with times of industrious building alternating with long periods of stag- nation. ${ }^{4}$ In $\mathrm{I} 248$, the first stone was laid for the cathedral that would bring the diaphanous architecture of French Gothic to the Rhineland, although it would only be completed 632 years later - and even then only provisionally. In the Middle Ages the tall, light choir with its seven apse chapels was closed off with a wall that would remain in place until well into the nineteenth century. Around I300, a cycle of fifteen stainedglass windows was installed in the clerestory of the choir and can be seen there to this day. The main zone features a colourful cycle of fortyeight kings depicted in pairs. The background alternates between red and blue, and yellow is used for the many details. Above this, the frame is largely filled with lightly coloured, ornamental patterns. It is only in the quatrefoil tracery up in the window's peak that colour returns in an abstract pattern.

After Cologne had become part of Prussia following Napoleon's defeat in I8I5, it was decided that the cathedral, which at that time consisted of little more than the choir and the stump of an unfinished tower of the western facade, would be completed as a national monument to Germany's unity. In I863, the nave and transept were completed, and the towers reached their highest point in I880. For the design of the nineteenth-century windows in the clerestories of the nave and transept, the medieval lay-out was largely readopted, only this time with saints and characters from the Old and New Testament instead of kings.

From May I942, Cologne was heavily bombed by the Allies. The cathedral was not spared, but at the end of the Second World War its dark mass still towered over the ruined city, severely damaged yet still standing. As a precaution, in 1939 the medieval windows had been moved to safe storage but, a small number excepted, the nineteenth-century windows 


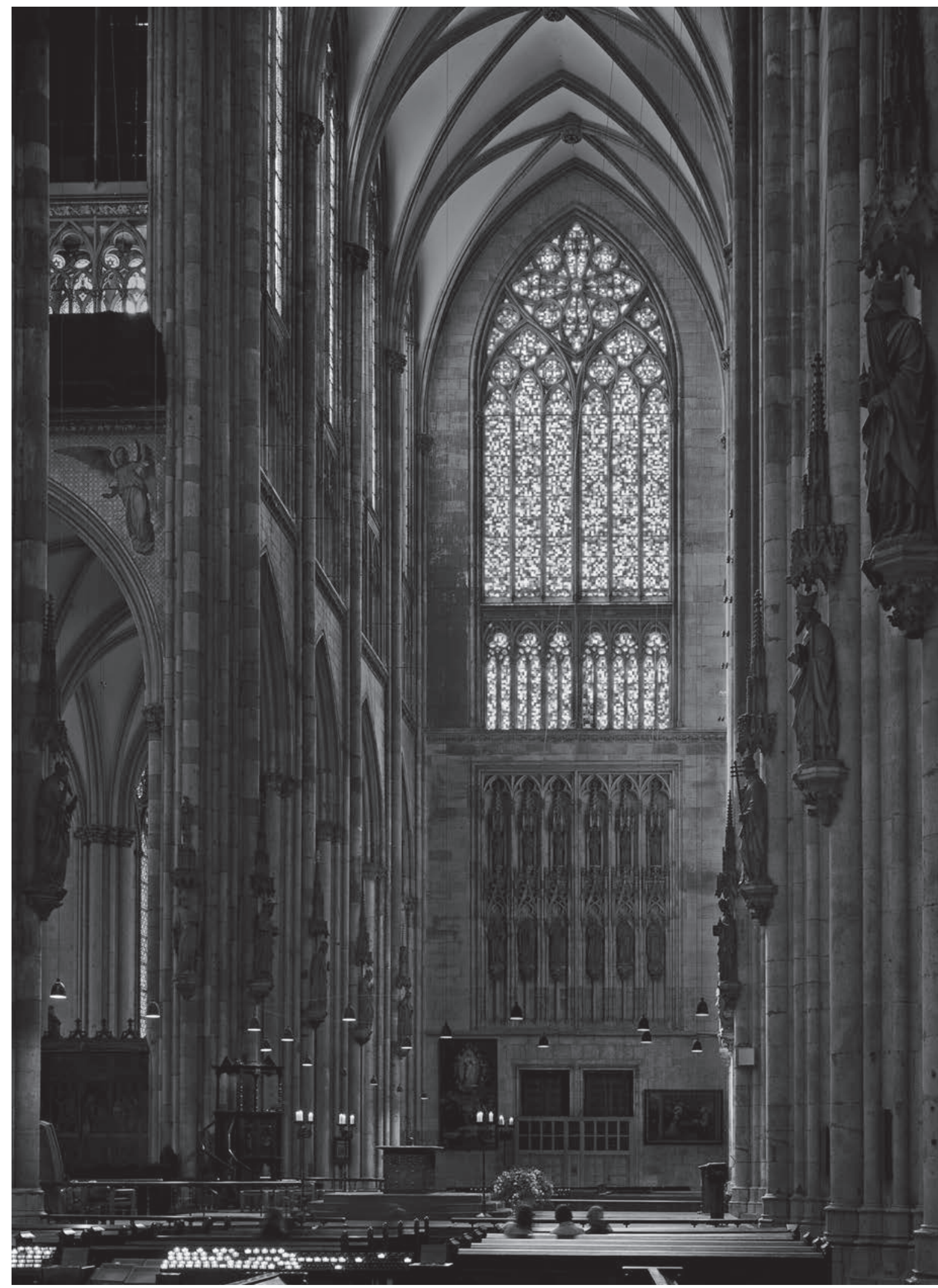

Fig. I. Gerhard Richter, Cologne Cathedral Window, 2007, $2300 \times 900 \mathrm{~cm}$, genuine antique glass, mouthblown. (C) Gerhard Richter 2016 (II69). 
had remained in place and these were shattered by air pressure during the bombings. After the war, the medieval windows were reinstalled in the choir, but the nave and transept were given new ornamental glazing that created a cold light within the church. The large window frame in the southern transept was filled with opaque, nearly colourless glass by Wilhelm Teuwen in I947, a solution that was perceived as unsatisfactory from the beginning and that fuelled the longing for the return of colour.

At the beginning of the new millennium, the cathedral's chapter turned to fellow townsman Gerhard Richter and asked him to design new glazing for the window in the southern transept. They suggested he continue the programme of the older windows, and for the six windows in the bottom zone the chapter envisioned figurative depictions of six contemporary, Catholic martyrs, all victims of fascism. Among these would be Edith Stein, the philosopher, who had been born into an orthodox Jewish family but converted to Catholicism and was ordained as a Carmelite nun. Nevertheless she did not escape the persecution of the Jews and was gassed in Auschwitz in 1942. The Polish Franciscan priest Maximilian Kolbe, imprisoned in Auschwitz for taking part in the resistance and condemned to die there by starvation in 194I, was also be included in the series. ${ }^{5}$

In 2002, the chapter discussed the desired theme with Richter, but when he revealed his design to them in his studio several months later, they were greatly surprised. They had expected something very different from the grid of coloured squares that Richter proposed. ${ }^{\circ}$

\section{Why Richter?}

Exactly what had motivated the chapter to ask Richter for this commission cannot be deduced from the literature. Naturally, Richter's reputation as one of Germany's leading artists must have played a role, but there are other considerations that may have made Richter a likely choice for this specific theme in this particular place.
Richter was born in Dresden in 1932 into a Protestant family, but as an adolescent he abandoned religion. Nevertheless, Richter states that he knows and values the Catholic Church and much prefers Christian teachings to those ideologies that promise people paradise on earth (Richter grew up under fascist and communist rule and fled to West Germany in 196I). ${ }^{7}$ Yet Richter never became a Catholic, nor did he join any other religion, although he did tell curator Robert Storr of the Museum of Modern Art in New York in 2002 that he was moved when his children were baptized Catholics: 'That is my culture, my history, the last 2000 years were Catholic and it was not so bad. ${ }^{8}$ In his work, Richter has repeatedly referred to Christian iconography by reusing images from art history, and he also, explicitly or implicitly, displayed the sign of the cross in several of his works. ${ }^{9}$

When considering the design they were asking for, the church council must have taken into account the fact that, throughout his oeuvre, Richter had produced both abstract and figurative paintings based on photos, some of them referring directly to the Second World War. ${ }^{\text {I0 }}$ Moreover, Richter's Atlas (the ever-expanding collection of photos, newspaper and magazine cuttings, and drafts, glued to boards, which sometimes serves as a source for his works and which was published as a book) from an early stage featured images referring to the Holocaust, and Richter considered capturing this nearly incomprehensible mass-murder several times, although all of these attempts failed. ${ }^{I I}$ Richter contemplated turning four of these photos into large grey paintings and including them in his design for a monumental, public, $20 \times 3$-metre artwork for the lobby of the new Reichstag building in Berlin, the sketches of which can also be found in Atlas (Fig. 2). ${ }^{12}$ But in the end he chose not to carry this proposal forward ('Perhaps it was shame or pity that held me back. I never figured it out. ${ }^{{ }^{13}}$ ) and the finished work consists of six enormous, paired glass panels executed in black, red, and gold (Schwartz, Rot, Gold, I999).

The chapter of the cathedral in Cologne must have been aware of Richter's previous and controversial attempt to find a way of depicting a 


\section{Wouter Weijers}

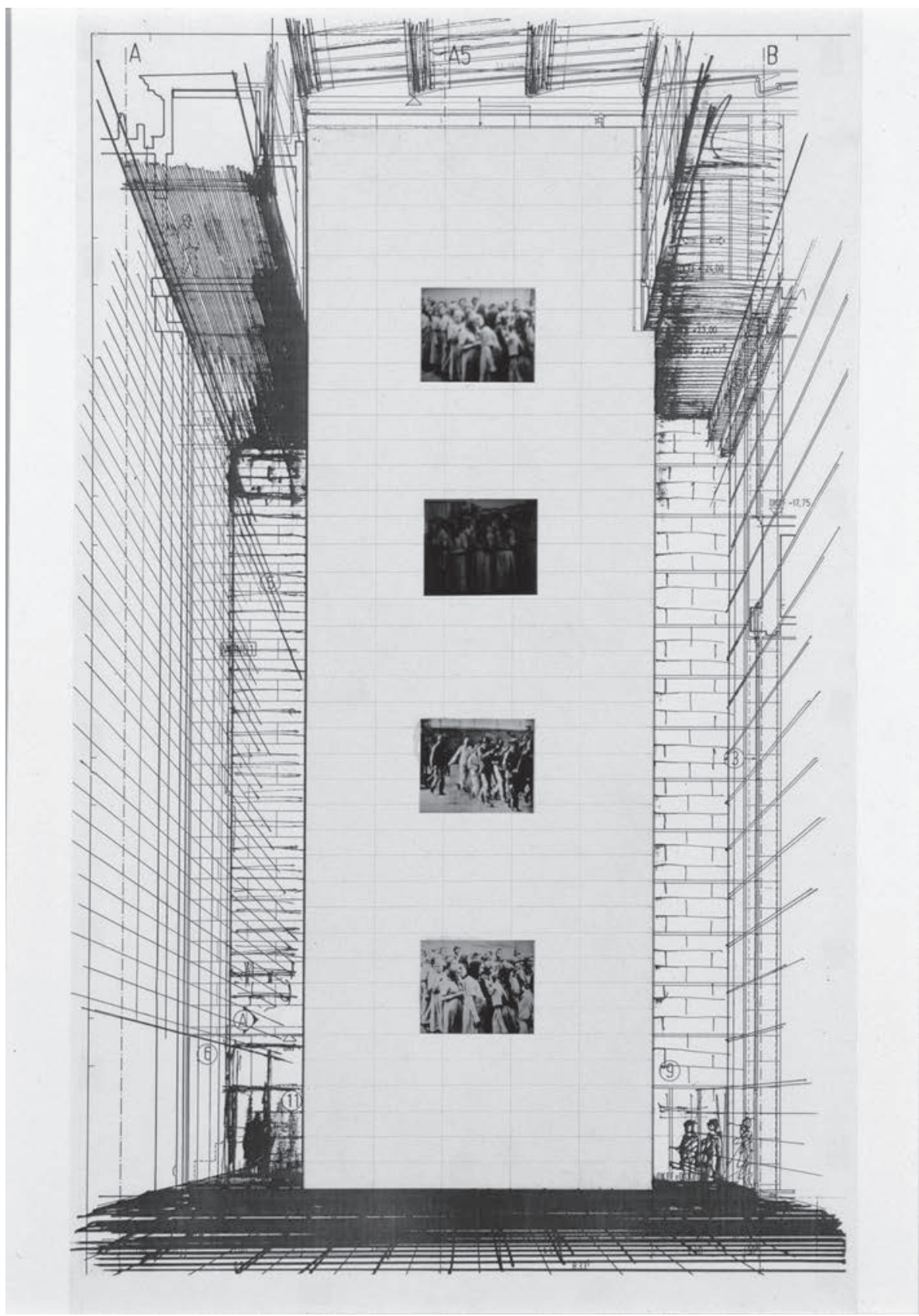

Fig. 2. Gerhard Richter, Reichstag, I997, in: Gerhard Richter, Atlas, Sheet 648, 7I × 5I.7 cm, Munich: Städtische Galerie im Lenbachhaus und Kunstbau. (C) Gerhard Richter 20 I6 (II55).

contemporary form of martyrdom. Dead (Fig. 3) is one of the paintings in the I5-part cycle October 18, 1977 from I988. The date refers to the-day on which three members of the left-extremist Rote Armee Fraktion (RAF) committed suicide, or, as some believe, were murdered. ${ }^{14}$ Earlier, on 9 May 1976, another member of the
RAF, Ulrike Meinhof, had hanged herself in her cell in the same prison. The painting Dead is derived from a photo of her dead body, which appeared in Stern magazine on I6 June I976. ${ }^{\text {Is }}$ Yet here we also see a distant echo of The Body of the Dead Christ in the Tomb (I52I) by Hans Holbein the Younger. 


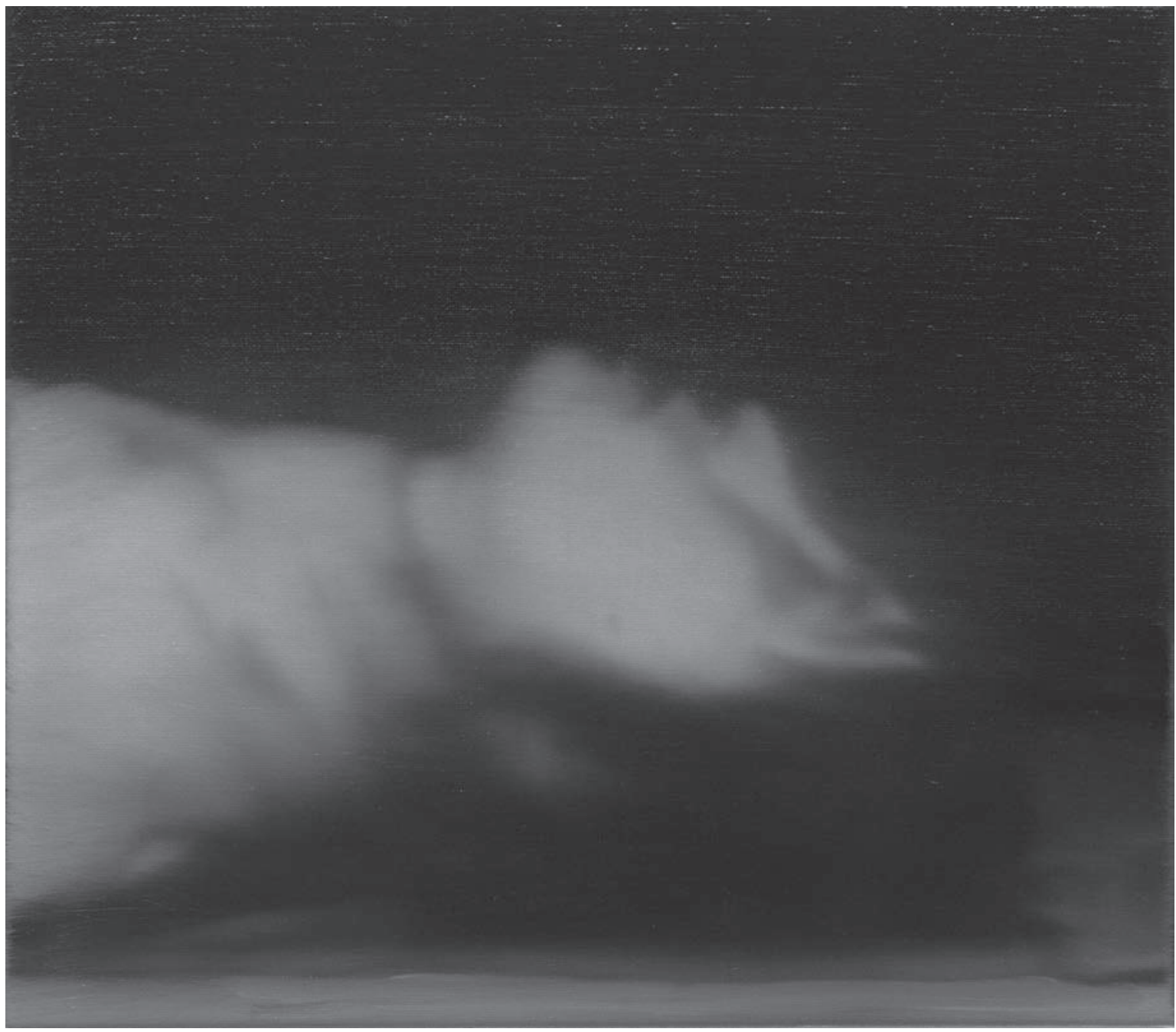

Fig. 3. Gerhard Richter, Dead, I988, $35 \times 40 \mathrm{~cm}$, oil on canvas, New York: The Museum of Modern Art. (C) Gerhard Richter 2016 (I 55 ).

\section{A Lament for Loss}

Meinhof and the three other prisoners were part of the first generation of RAF members and were responsible for a series of anti-fascist and anti-capitalist-inspired terror attacks that killed more than thirty people at the beginning of the I970s. Richter rejected the RAF members' ideologically- and utopically-motivated violence, but wrote in a letter to Stefan Germer that he was impressed by their uncompromising will and absolute courage. ${ }^{16} \mathrm{He}$ painted the works of October 18, 1977 in an 'almost helpless attempt to give shape to feelings of pity, grief and dismay' without offering a view of an answer, statement or opinion. They provoke 'contradiction because of their helplessness, because of their impartiality'. ${ }^{17}$

But October 18, 1977 also refers to suffering and sacrifice for a higher cause, and the succession of the paintings forms, to Lisa Saltzman's mind, a contemporary Passion cycle that includes arrest, incarceration, death, and burial: '[...] a set of relations, an array of affinities in which Christian iconography comes together with an avowedly painterly practice, producing something of a secularised cycle of martyrdom or, at the very least a commemorative cycle of paintings. ${ }^{18}$ But according to Saltzman the question 


\section{Wouter Weijers}

is whether these subjects of history are laid to rest, mourned and remembered through their representation in painting, or whether this cycle offers up not closure but 'infinite repetition, the inevitable and intractable deferrals of a fundamentally melancholic disavowal'. ${ }^{9}$

All paintings in this cycle are grey and were painted in a vague and diffuse way, as if something has been obliterated, writes Stefan Germer. ${ }^{20}$ Richter has subjected the original photos to a kind of erasing, which pushes back the image in such a way that it seems to dissolve. Thus the past is simultaneously brought closer and blurred. In a striking observation, Germer sees the paradox of approach and distancing return in the museum hall, where, from a distance, visitors can still view the paintings as images referring to a historical reality, but where these images also seem to dissolve in an indefinable grey when approached. To Germer, this oscillation between distance and proximity, past and present, absence and presence, forms the essence of these paintings. However, he also concluded that this attempt at a contemporary form of history painting is unable to explain and transcend the events, and, what's more, that Richter is very much aware of this inability. Therefore these paintings must be seen as 'monuments of mourning', as 'a lament for loss'. ${ }^{21}$ Moreover, the cycle does not only mourn dead people but also art's inability to give these deaths meaning in our day and age. ${ }^{22}$ But even though this kind of emptiness and absence forms the core of Richter's art, that which the image refers to still resonates in the painting. Such thoughts on Richter's RAF cycle, in my opinion, are also applicable to works that seem to be very different, like his Cathedral Window.

\section{Light and Colour}

Initially, Richter tried to meet the wishes of the cathedral chapter in Cologne by making two small designs that, although they did not display the Catholic martyrs mentioned, were based on photos of executed victims of Nazism. Yet he decided, as he had done before in respect of his first design for the hall of the Reichstag building, that such shocking scenes of people being hanged and shot were inappropriate, and that other historical motifs would be inadequate to reflect our own position at the beginning of the twenty-first century. ${ }^{23}$ In addition, the window would have to respect the religious context and it should transcend earthly life. The dialectic relationship between presence and absence that he played out in his photo paintings would have to find its own unique expression in a different, specific medium: glass.

Although the design that Richter consequently presented to the chapter seems to steer a radically different course, the transformation that Lisa Saltzman discerns in the 'figurative' painting cycle to which Dead belongs - 'the movement from the particular to the generic, from the specific to the symbolic, from the historical to the art-historical, from the secular to the sacred, from the known to the unknown' - also returns in the 'abstract' Cathedral Window. ${ }^{24}$ Even though both Cardinal Meisner and Richter himself may not think it is a Catholic window, it is because of this transformation that - according to the Bishop of Würzburg, Friedhelm Hofmann - Richter's work reaches into a 'metaphysical sphere which also inspires religious associations'. ${ }^{25}$ It seems that the absence of Catholic iconography does not impede the attribution of spiritual expressiveness to the window, and the idea that the spiritual could be reached solely on the basis of light and colour had already been described by $\mathrm{Ab}$ bot Suger of Saint-Denis in the twelfth century.

On the occasion of the consecration of the new Gothic chancel in the abbey church of Saint Denis on I4 June I I44, built under his supervision, Suger ordered an inscription praising the light-drenched, diaphanous structure of the architecture: 'For bright is that which is brightly coupled with the bright [...]. ${ }^{26}$ In a whole of aesthetic and religious experiences, the new windows were supposed to illuminate the minds. ${ }^{27}$ Gilded copper letters on the new church doors read:

Bright is the noble work, but being nobly bright, the work should brighten the minds, so that they may travel, through the true lights 
to the True Light [...] The dull mind rises to truth through that which is material and in seeing this light, is resurrected from its former submission. ${ }^{28}$

Thus the faithful would be brought from the lower to the higher world in a symbolic way: 'transferring that which is material to that which is immaterial'. ${ }^{29}$ Suger saw the radiance of the multicoloured windows and gems as analogous to God - as an abstract, spiritual 'likeness': 'God is light' ( John I. 5) - but also as 'anagogical' in character, meaning that, through the material things, ${ }^{30}$ the spirit can be brought to the "true light that illuminates each person' (John I. 9).

So the spiritual and metaphysical dimensions that some admirers discern in Richter's window are part of an age-old Catholic tradition. Nevertheless, an appeal to this tradition alone cannot explain the window: Richter's relationship to history and religion is too complicated for that. To him, it is impossible for the window's pied beauty to lead to a divine truth. Richter feels art in our age lacks the spiritual foundation on which Suger's reasoning was based. The art of our day will have to make do without ideology, religion and faith. This does not mean that he denies the possibility of transcendence, however. Just as it was for Suger, art is to Richter 'the making of an analogy for something nonvisual and incomprehensible: giving it form and bringing it within reach' ${ }^{3}$

Perhaps it was this thought that inspired Richter to make his design proposal for the cathedral window to the Cologne Chapter. But this window would also have to reflect our own historical position at the beginning of the twenty-first century. Richter's proposal was a window 'as sublime as the godhead, as inexplicable as life, indefinable and without purpose'. ${ }^{2}$

\section{The Window}

For an artwork in an important religious edifice, Richter's Cathedral Window has remarkably prosaic origins. In I966, Richter made a number of works showing only coloured squares that were painted flatly on the canvas, placed alongside each other, and varying in number from six to I92 per canvas - the seed of the window in Cologne. At first glance they seem abstract and minimalist, but they are in fact paintings of 'ready-made' colour samples as they can be found in paint shops: Richter's version of Pop Art. ${ }^{33}$ The coloured planes are placed in a grid without any internal hierarchy and show nothing more than their own appearance: 'there is absolutely no higher form of realism. ${ }^{34}$

During the years I97I-74, Richter worked on a second series of samples, but this time he determined the colours himself through a methodical series of colour mixings, first by systematically mixing yellow, red, and blue and then light grey, dark grey, and green. This resulted in an arithmetic succession of colour combinations that seemed endless, were it not for the fact that the variegations were no longer discernible after I024 mixings. He repeated all of these I024 colours four times in the painting 4096 Colours (1974, $254 \times 254 \mathrm{~cm}$, lacquer on canvas) this time arranging the coloured squares in a chessboard pattern and directly against each other, without white interspaces (Colour Plate $\mathrm{Xv}$ ). ${ }^{35}$ This structure formed the basis of the design for the window in the cathedral in Cologne.

After his first attempts at a design for the window had failed, and, by his own admission, he considered resigning the commission, Richter overlaid a template of the Gothic tracery of the window onto a picture of $4096 \mathrm{Col}$ ours and concluded that this was the only way he could realise the commission..$^{36}$ Although Richter had previously used a similar colour pattern for a window in the stairwell of a private home in 1989, the question remains why he chose to implement this structure in an explicitly religious context. Richter had started to make his paintings of colour samples out of opposition against both the spiritual aspirations of the expressionistic view on colour as professed by, amongst others, Wassily Kandinsky in his book Über das Geistige in der Kunst from I9II, and the dogmatization of colour values and colour relations in (neo-)constructivist chromatics. In an interview with Benjamin Buchloh, he called his colour screens 


\section{Wouter Weijers}

'an assault on the falsity and the religiosity of the way people glorify abstraction, with such a phony reverence. Devotional art - all those squares - Church handicrafts'. ${ }^{37}$ Some fifteen years later, Richter designed his own version of church handicrafts in the devotional setting of the Cathedral of Cologne, and presented a structure that, analogous to nature, he sees as 'a becoming, a coming into being, a being and a being in that way $[\ldots]$ logical, perfect and incomprehensible. ${ }^{3}{ }^{8}$

Richter's Cathedral Window is composed of seventy-two colours, randomly distributed across an even grid..$^{39}$ Every colour is repeated and mirrored seventy-two times in the window. The division of the colours across the surface is based on the concept of chance that Richter applied frequently in his work, with objectivity and arbitrariness serving 'to produce paintings that I haven't made'. ${ }^{40}$ A specially designed computer programme determined the positions of the (numbered) colours, yet some restrictions were imposed. An entirely random distribution might have led to undesired effects, like the clustering of identical or similar colours in certain places. For this reason, an even distribution of the colours over the entire surface was programmed, although every colour could still end up next to any other one in an anarchistic and egalitarian way. Although the colours were evenly distributed, the colour balance proved to be different between several test setups for the window and the overall colour tone was adjusted to the darker setup of these trials. ${ }^{41}$ So, although there was much in the window that appeared unforeseen and unexpectedly, Richter had to, or wanted to, take a number of important aesthetic decisions himself. This also goes for the size of the squares, a question that was finally decided by eye. Another important intervention was Richter's decision to mirror parts of the pattern to create some order and calm in the vibrant collection of colours: in the finalised window, the first vertical lace frame is reflected in the third, the second in the fifth, and the fourth in the sixth - although this has to be pointed out to most visitors before they actually notice it. 'By taking chance as the guiding principle in composing the colour fields [...]', writes Birgit Pelzer, 'Richter sets a switch point between decidable and undecidable, between controllable and uncontrollable - an in-between point, a neither-nor, an exchange. ${ }^{32}$

\section{Virtual Infinity}

'The colour fields reveal something finite that is capable of infinite propagation. Thus chance which is by definition something unintentional that happens without reflection, without rules, without choice, without reasons - is assigned here to a virtual infinity [...].43 Over eleven thousand hand-blown glass squares make up the material component of a window that lives off the interaction with incorporeal light. This light is also at the mercy of the season of the year, the time of day, changing weather conditions: coincidences of which the fleeting, traceless impressions reach us by the grace of the material glass. Due to the use of that material in this place, colour and light do not refer solely to their own appearance but direct us toward what may be called the ineffable, the unknown, the invisible: categories we usually associate with religion, or with the sublime.

In a contribution to the catalogue of Documenta 7 (Kassel, I982), Richter had described qualifications such as the unknown, the ungraspable, the infinite as 'negative names' for 'a reality we can neither see nor describe but we may nevertheless conclude to exist. ${ }^{34}$ For thousands of years, writes Richter, we have depicted what can be neither seen nor understood by way of substitute images, but with abstract painting we created a better means to approach what cannot be described, because abstract art visualises 'with the greatest clarity, that is with all the means at the disposal of art, "nothing".

In Caspar David Friedrich's painting Monk by the Sea (c. I809, Nationalgalerie, Staatliche Museen, Berlin) a tiny monk standing on the beach stares at the immense space above the sea and contemplates a 'nothing' that is at the same time an 'everything' to him. To Richter, this no longer applies to us: 'We no longer experience the "omnipresence of God in nature". To us, everything is empty. ${ }^{25}$ Compared to the art 
of Friedrich, whom he greatly admires, Richter sees the art of our time as no more than 'a mirror of our spiritual poverty, our desolation and lostness. ${ }^{46}$ Nevertheless, he concludes his text for the Documenta 7-catalogue with the phrase 'Art is the highest form of hope'. ${ }^{47}$

To my mind, Richter's hope is to not give up art's aspirations, despite all the feelings of desolation and lostness. As early as 1962 he wrote:

Art is making sense and giving shape to that sense, like the search for God or religion. We are all aware that making sense and picturing are artificial like illusion; but we never can give them up. For belief $[\ldots]$ is our most important characteristic. ${ }^{48}$

In order to visualize in his oeuvre that which is virtually infinite, on account of the unique qualities of the material Richter has often used glass which pairs optical precision with its absence. ${ }^{49}$ In other works of art in his oeuvre, such as the many mirror works (e.g. Six Gray Mirrors, 2003) and the sculptures that consist of combinations of window panes (e.g. 7 standing Panes, 2002, and 11 Panes, 2003) Richter aimed at 'transmuting the insubstantial through a very precisely articulated substance'.$^{\circ}$ Whether they are mirroring images that allow the spaces behind or above us to enter our field of vision, or linked or stacked panes that become increasingly blurred as one looks through them, they generate a sense of both a depth and a reach beyond their own 'thingness'. I think the same goes for Richter's Cathedral Window.

In Richter's design the window is denied its traditional role as a picture carrier, writes Dorothée Brill. ${ }^{\text {II }}$ Its undirectedness, randomness and lack of drama reflect the absence of any will to pictorial creation. Instead, the window is perceived as exactly what it is: a pattern of squares of coloured glass. Its patterning has been compared to mosaics or to pixels, but whereas in these cases the coloured particles form a potential repository for every possible image, in the Cathedral Window they fail to merge into a single entity. Even if we are willing to consider such dots - whether digital or physical - as the building blocks of a potential image, the window presents us with nothing but coloured squares, as if, even at a great distance, we are always standing too close. The desire to create a representation of the divine is thus halted, 'It's just that it doesn't appear', as Richter himself says..$^{52}$ And yet, as he wrote years earlier about his abstract paintings: 'Accustomed to recognising real things in paintings we refuse, justifiably, to consider colour alone (in all its variations) as what the painting reveals, and instead allow ourselves to see the unseeable, that which has never before been seen and indeed is not visible. ${ }^{53}$ Our refusal to take colour (or the work of art) at face value, tempts us to see what can indeed not be seen. Thus, the 'nothing' that Richter connects to abstract art cannot simply be conceived as a reference to a potential spiritual dimension; it is also the result of the powerlessness of today's art. As Brill writes: 'Richter's conclusions regarding the non-representational nature of the divine arise not - or not only - from spiritual insight, but from his preoccupation, for decades now, with the nature of pictures and their limits. ${ }^{54}$

\section{The Melancholy Art}

The window's transcendental implications are in line with a long cultural-historical tradition, without which Richter's window would be unthinkable. Richter reflects this history but at the same time he does so realizing that, in a reversal of Caspar David Friedrich's Monk by the Sea, the Divine 'everything' is an everyday 'nothing', which means that the window can also be seen as an embodiment of loss. Richter realises that his artworks in their own guises can show a glimpse of the ineffable, but that they do this in a modern void, and that this void also concerns the modern artwork itself.

Richter's window extends on history and can also be explained from history, from medieval light mysticism to the modernistic grid, including the subversion of modernist myths by using ready-made images and chance. Yet the window also relates to the fundamental realization that history is irrevocably past.

The way in which Richter's Cathedral Window exemplifies absence and loss shows a striking parallel with what art historian Michael Ann 


\section{Wouter Weijers}

Holly writes in her book The Melancholy Art (20I3) about the discipline of art history itself. Artworks that come to us from earlier centuries can still be just as much present as material objects as they were at the time they originated. Yet that time is also lost to us, and with it everything that once gave the artwork life: "We have a "loss without a lost object" (an authentic melancholic predicament) in which the object is both held onto and gone astray simultaneously'ss Even though art history is concerned with recovering what was lost or forgotten, in Holly's eyes the discipline can never repair that loss. It is, she thinks, the awareness of this absence in that which is present that gives art history its melancholy undertone.

There is nothing wrong with attempts to give meaning to the artwork, she writes, but there will come a moment when interpretation falls short and when nothing more can be said about something material that transcends our fragile comprehension. 'Should we call this melancholic recognition the aesthetic moment?' she wonders. ${ }^{56}$

Holly knows from experience how fascinating art-historical research can be. But she also thinks 'art' can never be attenuated to what we reductively call 'history', ${ }^{57}$ and she recognises the threat of stripping the material work of art of 'its awe, its affects, its "strangeness and astonishment" in Nietzsche's terms, no doubt the reason why still art still matters in the first place. ${ }^{58}$

Holly calls the objects from the past "visual orphans', because they stand before us in the present while the worlds from which they came are long gone. To her, writing about these objects is the activity that tries to build a bridge across the void, but in doing so it only reveals the absence that the passage of time bequeaths to us: 'whatever [the writer] wants to say, it is nothing', she quotes Maurice Blanchot. ${ }^{59}$ Writing echoes the distance between the past and the present by interjecting the opaque membrane of language. It may reveal the absence that is the past, but it is also the activity that perpetually resurrects the desire to create meaning where it might no longer exist. ${ }^{60}$

We, too, can consider these insights about our treatment of artworks from the past while we aim our gaze at Richter's Cathedral Window and think of it as a contemporary, translucent membrane between past and present, the visible and the invisible that shows us a strange lostness that is palpably present. ${ }^{61}$

Notes

I Barbara Schock-Werner, 'The New Window as an Integrated Part of the Cathedral's Historical Glazing', in Gerhard Richter - Zufall: Das Kölner Domfenster und 4900 Farben (Cologne: Kölner Dom and Walther König, 2007), pp. I09-I6 (quote on p. II6).

2 Meisner quoted in 'Kardinal Meisner 'Dom-Fenster passt besser in eine Moschee!', Express, 29 August 2007 $<$ http://www.express.de/kardinal-meisner--domfenster-passt-besser-in-eine-moschee---22219834> [accessed June 20I6].

3 Richter in 'Schlingensief für Jesus', Süddeutsche Zeitung, I6 December 2008, <http://www.sueddeutsche. de/kultur/kardinal-meisner-ueber-moderne-kunstschlingensief-fuer-jesus-I.767478> [accessed June 20I6].

4 This short history is based on Schock-Werner, pp. I09-I6; Hubertus Butin, 'Gerhard Richter's Window for Cologne Cathedral', in Gerhard-Richter - Zufall, pp. II7-24; Gerhard Büttner, Kirche sein als communio (Berlin: LIT, 20I5), pp. II7-24.

5 The other four (priests Rupert Mayer, Karl Leisner, Bernhard Lichtenberg, and Catholic unionist Nikolaus Gross) were also directly or indirectly killed

because of their opposition to fascist ideas or practices. All six of them were either canonized (Stein and Kolbe) or beatified by popes Paul VI and John Paul II.

6 Barbara Schock-Werner, in Gerhard Richter: Das Kölner Domfenster, written and directed by Corinna Belz (WDR | Arte and Zero One Film, 2007).

7 Gerhard Richter, 'Interview mit Hans Ulrich Obrist November 2006', in Gerhard Richter, Text, 1961 bis 2007: Schrifte, Interviews, Briefe, ed. by Dietmar Elger and Hans Ulrich Obrist (Cologne: Walther König, 2008), pp. 538-39 (quote on p. 538).

8 Robert Storr, Gerhard Richter: Forty Years of Painting (New York: The Museum of Modern Art, 2002), p. 83 .

9 E.g. Kreuz, I996, and the series Abstraktes Bild (Rhombus), I998, where, in Robert Storr's opinion, the implied vertical body with stretched-out arms is present in the axial orientation. Storr, Gerhard Richter: Forty Years, p. 83 .

Io See for example Bomber, I963, and Onkel Rudi, I965.

I I The first attempt in 1967 consists of a group of photos about the persecution of the Jews taken from books, some of which are diffused or coloured in. Gerhard 
Richter, Atlas (Cologne: Walther König, 2006), panels I6-20. The second attempt was a larger group of photos, entitled Holocaust, which was included in Atlas in 1997 (Atlas, panels 635-46). Much more recently, four photos that were taken clandestinely at the gas chambers of Auschwitz-Birkenau form the starting point of four abstract paintings entitled Birkenau, 20I4. Initially, Richter copied the four photos on the canvasses, but these are longer traceable under the abstract painting-over in the finished work. The film Gerhard Richter Painting, written and directed by Corinna Belz (WDR / Arte and Zero One Film, 20II) [on DVD], shows one of these photos hanging next to Richter's design for the Cathedral Window in his studio.

I2 Richter, Atlas, panels 647-55.

I3 Richter, quoted in Dietmar Elger, Gerhard Richter Maler (Cologne: DuMont Literatur und Kunst, 2002), p. 4I 8 .

I 4 The three were Andreas Baader, Gudrun Ennslin and Jan-Carl Raspe.

I5 Robert Storr, Gerhard Richter, October 18, 1977 (New York: The Museum of Modern Art, 2000), p. III.

I6 Richter quoted in Stefan Germer, 'Ungebetene Erinnerung' in exh. cat. Frankfurt am Main: Museum Haus Esters, Krefeld / Portikus, Gerhard Richter 18. Oktober 1977 (Cologne: Walter König, I989), pp. 5I-53 (quote on p. 5I).

I7 Gerhard Richter, 'Notizen November I988 (für die Pressekonferenz Februar I989 - Museum Haus Esters, Krefeld)', in Gerhard Richter, Text, 1961 bis 2007, pp. 205-07 (quote on pp. 206-07).

I8 Lisa Saltzman, 'Gerhard Richter's 'Stations of the Cross': On Martyrdom and Memory in Postwar German Art', Oxford Art Journal, 28, I (2005), 25-44 (quote on p. 42).

I9 Saltzman, p. 43.

20 Germer, pp. 5I-53.

2 I Ibid., p. 5I.

22 Ibid., p. 52.

23 Butin, p. II8.

24 Saltzman, p. 44.

25 Hofmann quoted by Butin, p. II7. Hofmann spoke these words in his eulogy at the awarding ceremony of the 'Art and Culture Prize of the Catholic Church' to Gerhard Richter on 20 November 2004.

26 Suger, 'De rebus in administratione sua gestis / On what was done under his administration' in Abbot Suger: On the Abbey Church of St.-Denis and its Art Treasures, edited, transl. and ann. by Erwin Panofsky (Princeton, NJ: Princeton University Press, I946), pp. 4I-8I (quote on p. 5I).

27 Suger based his neo- Platonic light mysticism on a fifth-century text originating from Syria, which he wrongly thought was written by Dionysius the Areopagite, a convert of Paul, in Athens. Otto von Simson, Die Gotische Kathedrale (Darmstadt: Wissenschaftliche Buchgesellschaft, I979), pp. I48-49.
28 Suger, pp. 48-49.

29 Ibid., p. 65.

30 'I can be transported from this inferior to the higher world in anagogical manner', Suger, p. 65; Von Simson, pp. I63-65.

3 I Gerhard Richter, 'Notizen I98I', in Gerhard Richter, Text, 1961 bis 2007, pp. II9-20 (quote on p. I20).

32 Richter in conversation with Dorothée Brill. Cf. Dorothée Brill, 'That's as Far as it Goes', in Gerhard Richter: Panorama, ed. by Mark Godfrey and Nicholas Serrota (London: Tate, 20II), pp. 245-54 (quote on p. 254).

33 Richter, in Gerhard Richter: Das Kölner Domfenster, written and directed by Corinna Belz (WDR | Arte and Zero One Film, 2007).

34 Gerhard Richter, 'Interview mit Peter Sager 1972', in Gerhard Richter, Text, 1961 bis 2007, pp. 64-67 (quote on p. 66).

35 Storr, Gerhard Richter: Forty Years, p. $5 \mathrm{I}$.

36 Gerhard Richter, 'Notizen zur Pressekonferenz, 28. Juli 2006', in Gerhard Richter, Text, 1961 bis 2007, pp. 526-28 (quote on p. 527).

37 Gerhard Richter, 'Interview mit Benjamin $\mathrm{H}$. Buchloh 1986', in Gerhard Richter, Text, 1961 bis 2007, pp. I64-89 (quote on p. I73).

38 Gerhard Richter, 'Notizen I985', in Gerhard Richter, Text, 1961 bis 2007, pp. I40-44 (quote on p. I42).

39 Although it has been claimed that these seventy-two colours were derived from the colours of the medieval windows in the cathedral, I have not been able to find confirmation of this.

40 Richter in conversation with Birgit Pelzer. Cf. Birgit Pelzer, 'The Asymptote of Chance', in exh. cat. London: Serpentine Gallery, Gerhard Richter 4900 Colours (Berlin: Hatje Cantz, 2008), pp. II7-3I (quote on p. II7).

4I Gerhard Richter: Das Kölner Domfenster, film written and directed by Corinna Belz (WDR / Arte and Zero One Film, 2007).

42 Birgit Pelzer, 'Chance as Partner', in Gerhard Richter - Zufall, pp. I25-43 (quote on p. I38).

43 Ibid., p. I26.

44 Gerhard Richter, in exh. cat. Kassel, Documenta 7 (Kassel: D + V Paul Dierichs, I982), I, pp. 84-85 (English transl. on p. 443).

45 Gerhard Richter, 'Interview mit Irmeline Lebeer I973', in Gerhard Richter, Text, 1961 bis 2007, pp. 72-83 (quote on p. 82).

46 Gerhard Richter, 'Notizen 1988', in Gerhard Richter, Text, 1961 bis 2007, pp. 203-04 (quote on p. 203).

47 Richter, in exh. cat. Kassel, p. 85 (English transl. on p. 443).

48 Gerhard Richter, 'Notizen I962', in Gerhard Richter, Text, 1961 bis 2007, pp. I4-IS (quote on p. I4); Storr, Gerhard Richter: Forty Years, p. 86.

49 Rachel Haidu, 'Images of the World and the Inscription of History', in Gerhard Richter: Panorama, pp. 2OI-I3 (quote on p. 2I2). 


\section{Wouter Weijers}

50 Ibid., pp. $205-06$.

5I Brill, pp. 253-54.

52 Richter in conversation with Dorothée Brill, in Brill, p. 254 .

53 Richter, in exh. cat. Kassel, p. 85 (English transl. on p. 443).

54 Brill, p. 254.

55 Michael Ann Holly, The Melancholy Art (Princeton, NJ: Princeton University Press, 20I3), p. 6.

56 Ibid., p. xv.
57 Ibid., p. xv.

58 Ibid., p. xvii.

59 Ibid., p. xix.

60 Ibid., p. xx.

6I 'A strange lostness was | palpably present' ('Eine fremde Verlorenheit war | gestalthaft zugegen') is a line from the poem 'Stumme Herbstgerüche' by Paul Celan from the collection Die Niemandsrose (1963). For the English translation, see Poems of Paul Celan, transl. by Michael Hamburger (1996). 